Unused sphygmomanometer

H A Fleming, FRCP . . . . . . . . . . . 1659

Testing dyspeptic patients

$S$ Lipetz, FRCGP.

Anabolic steroids and anticoagulants

C W Howard, MRCP, and others.

Tuberculosis among immigrants in

Glasgow

K M Goel, MD, and others.......... 1660

Diet and coronary heart disease

Lindsay M Elliott, MB ............. 1660

Risk of coronary heart disease in

different populations

A R P Walker, DSC, and C Isaacson,

FRCPATH ................... 1660

Hazards of the sauna

S E Josse, MRCGP . . . . . . . . . . . . . . 1660

Suppression of intractable cough

C J Stewart, MD, and T J Coady, MB . . . 1660

Randomised clinical trials

S J Pocock . . . . . . . . . . . . . . . . . . . 1661

Delivery of postgraduate education

P J Tyrer, MD .................

Management of elderly demented

patients

J M S Pearce, FRCP

Cholestyramine in uraemic pruritus

O M Wrong, FRCP ............ 1662
Aerosols containing neomycin

I Friedmann, FRCPATH.........

I Friedmann, FRCPATH. . . . . . . . . . . $\ldots 1662$
Side effects of sodium valproate

H Bellman, MRCP, and E M Ross,

asal body temperature

R F Vollman,

Guillain-Barré syndrome and influenza

vaccine

W Ehrengut, MD .............. 1662

New strategies for drug monitoring

R H B Meyboom, MD . . . . . . . . . . . . 1663

Alkaline phosphatase isoenzymes in

dialysis bone disease

Th Mountokalakis, MD, and others..... 1663

Chronic urticaria after vasectomy

R P Warin, FRCP . . . . . . . . . . . 1663

Sexually induced headaches

N R Nutt, MB . . .............. 1664

Psychologically mediated abdominal

pain

I Taylor, FRCS $\ldots \ldots \ldots \ldots \ldots \ldots \ldots \ldots 1664$

1661 Management of the stove-in chest with

paradoxical movement

C P de Fonseka, FRCS.

Transient hypotension following

intravenous ethamsylate (Dicynene)

B Watson . . . . . . . . . . 1664
Peritoneal fibrosis

R D Rosin, FRCS . . . ............... 1664

$r^{\chi}$ Tetracycline and toxoplasmosis

P L Grossman, MD, and J S Remington,

MD ...................... 1664

Output of doctors

J Parkhouse, Ffarcs.................... 1665

Shortage of anaesthetists

J M Small, FRCS; C Langmaid, FRCs;

C Brun, FRCS, and D B Murray, DA; R M

Heddle, FRCS, and M R Lock, FRCS...... 1665

Peers or leaders?

R E Smith, FRCP . . . . . . . . . . . 1666

Risks and rewards

G T Watts, FRCS.

The cowardice continues

J P Anderson, FRCPED .......

Distinction awards

A P J Ross, FRCS; H Jacobs, MRCPSYCH . . . 1667

A confidence trick

M Jones, FDS; J P Beavis, FRCS, and G N

Boobbyer, FRCS; P W M Copeman, FRCP. . 1667

Professional indemnity

P G Stableforth, FRCS......

Resignation by profession

R R Drury, MB $\ldots \ldots \ldots 7 \ldots \ldots$

National Insurance contributions

J Kelly, MrCGP................ 1667
Correspondents are urged to write briefly so that readers may be offered as wide a selection of letters as possible. So many are being received that the omission of some is inevitable. Letters should be signed personally by all their authors.

\section{Unused sphygmomanometer}

SIR,-The two papers by Dr R F Heller and Professor Geoffrey Rose (4 June, pp 1441 and 1442) are appropriately published in the same issue as the preliminary report of the MRC pilot trial on mild to moderate hypertension. It has long been my contention that we should tackle much more adequately the severe hypertension that is already known to us.

As Heller and Rose indicate, many opportunities to measure the blood pressure are not taken. This even occurs when it is crying out to be measured. Not rarely one finds the modern general practitioner getting an electrocardiogram done long before using a sphygmomanometer even in a patient on the contraceptive pill complaining of severe headaches.

When raised blood pressure is recorded it is frequently not acted upon. In hospital the measurement may be made but may not be communicated to the general practitioner. One sees patients with complicated hypertension in whom a search of their old hospital notes shows that the anaesthetic chart years before records gross hypertension which has never been mentioned again.

It is my belief that we as a profession have some sort of mental block about the use of a sphygmomanometer and that the public might be better served if the health centre nurse or some other suitable person routinely recorded the blood pressure of all patients over the age of 40 attending their general practitioners.
Repeat observation should be made at suitable intervals.

Hugh A Fleming

Cambridge

'Fleming, H A, Cardiology, Peterborough Symposium, p 16. London, Pitman Medical, 1975.

\section{Testing dyspeptic patients}

SIR,-The article on the "Use of barium meal examination in dyspeptic patients under 50 " (4 June, p 1460) points out that of 100 dyspeptic patients under the age of 50 who underwent barium meal investigation no abnormality was found in 76 . We described ${ }^{1}$ a study in general practice showing the importance of stool benzidine testing in the examination of alimentary ulceration and comparing the results with those found by subsequent $x$-ray investigation. In 36 such cases a positive stool benzidine test led to the final diagnosis although the radiological findings were repeatedly negative. Perhaps the significance of testing for occult blood in the stool is not sufficiently appreciated.

\section{Edinburgh}

$S$ LIPETZ

${ }^{1}$ Lipetz, S, Sklaroff, S A, and Stein, L, British Medical fournal, 1955, 2, 172 .

\section{Anabolic steroids and anticoagulants}

SIR,-We should like to report the possible hazard of the potentiating effect of anabolic steroids on anticoagulant therapy. This has been reported previously ${ }^{1-3}$ but is not in our opinion widely appreciated. It seems possible that the use of these agents will increase, particularly in those patients with recurrent deep venous thrombosis who have not responded adequately to anticoagulant therapy.

Recently we have had experience of prolongation of thrombotest times following commencement of stanozolol treatment in patients previously well controlled on dicoumarol anticoagulation. One patient, a 42-yearold lady with recurrent deep venous thrombosis, was admitted with haematuria 16 days after starting stanozolol treatment at $5 \mathrm{mg} \mathrm{b} \mathrm{d}$. Thrombotest on admission was $1 \%$ $(20 \mathrm{~min})$. Treatment was given by infusion of fresh frozen plasma. In view of this experience a second patient, a 41-year-old man with deep vein thrombosis following hernia repair, was recalled 12 days after commencing stanozolol treatment in the same dosage. Thrombotest was $3.5 \%(225 \mathrm{~s})$. Anticoagulation was discontinued and restarted in lower dosage.

The effect of anabolic steroids on anticoagulant tolerance seems to depend on the chemical structure of the compound, the greatest reduction in anticoagulant requirement being produced by $\mathrm{C}_{17}$-alkylated derivatives of testosterone. The 17 alkyl group is introduced in the steroid molecule with the purpose of making anabolic steroids active by mouth $\mathrm{C}_{17}$-alkylated steroids are known to cause abnormalities of some liver function tests, abnormal BSP (bromsulphalein) retention, and increased serum transaminase levels. 